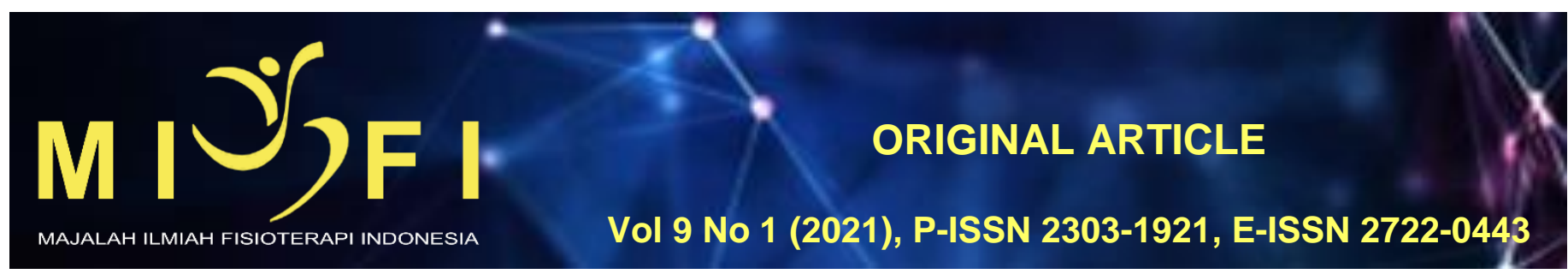

\title{
MENGGERINDA DAN MEMAHAT PATUNG SEBAGAI FAKTOR RISIKO CARPAL TUNNEL SYNDROME PADA PEKERJA DI KABUPATEN GIANYAR
}

\author{
Gusti Ayu Nyoman Nanda Wulantika', Ni Komang Ayu Juni Antari², Putu Ayu Sita Saraswati², \\ I Nyoman Adi Putra ${ }^{3}$
}

${ }^{1}$ Program Studi Sarjana Fisioterapi dan Profesi Fisioterapi, Fakultas Kedokteran, Universitas Udayana, Denpasar, Bali ${ }^{2}$ Departemen Fisioterapi, Fakultas Kedokteran, Universitas Udayana, Denpasar, Bali

${ }^{3}$ Departemen IImu Faal, Fakultas Kedokteran, Universitas Udayana, Denpasar, Bali gekwulan15@gmail.com

\begin{abstract}
ABSTRAK
Cedera pada pekerja dapat terjadi oleh karena posisi tangan saat bekerja yang tidak ergonomis dengan durasi waktu yang lama dapat menyebabkan terjadinya gangguan kesehatan. Salah satu gangguan musculoskeletal yang dialami yaitu Carpal Tunnel Syndrome (CTS). CTS merupakan suatu penyakit yang mengakibatkan tangan terasa kesemutan, mati rasa, dan menurunnya fungsi otot tangan. Hal ini diakibatkan karena adanya penekanan pada saraf medianus pada bagian pergelangan tangan. Penelitian ini merupakan penelitian yang menggunakan rancangan observasional analitik dengan metode pendekatan studi cross sectional. Penelitian ini dilakukan pada bulan februari sampai maret 2019 dengan total sampel 104 orang. Terdapat faktor risiko antara pekerjaan menggerinda dan memahat patung dengan kejadian CTS pada pekerja, dimana pekerjaan menggerinda memiliki faktor risiko yang lebih besar terhadap terjadinya CTS. Simpulan dari penelitian ini adalah terdapat hasil yang menunjukkan bahwa adanya hubungan yang signifikan antara pekerjaan menggerinda dan memahat patung terhadap terjadinya CTS.

Kata Kunci: CTS, memahat, menggerinda
\end{abstract}

\section{GRINDING AND STATUE SCULPTING AS CARPAL TUNNEL SYNDROME RISK FACTOR FOR WORKERS IN GIANYAR DISTRICT}

\begin{abstract}
Injury to workers can occur because of the position of the hand when working that is not ergonomic with a long duration of time can cause health problems. One of the musculoskeletal disorders experienced is Carpal Tunnel Syndrome (CTS). CTS is a disease that causes the hands to feel paresthesia, numbness, and decreased function of the hand muscles. This is caused by the pressure on the median nerve in the wrist. The current study uses analytic observational design with cross sectional study method. This study was conducted in February to March 2019 with a total sample of 104 people. There are risk factors between grinding and statue sculpting work with CTS incidents for workers, where grinding work has a greater risk factor for the occurrence of CTS. The study concludes that that there is a significant relationship between the work of grinding and statue sculpting the occurrence of CTS.
\end{abstract}

Keyword: CTS, sculpting, grinding

\section{PENDAHULUAN}

Bali dikenal dengan pulau yang kaya akan keindahan seni dan budayanya sehingga menjadi daya tarik tersendiri bagi wisatawan yang hendak datang ke Bali. Terdapat banyak sekali pengrajin seni seperti pemahat patung dan pekerjaan yang menggunakan mesin gerinda pada tukang ukir di Bali. Pekerjaan tersebut menjadi salah satu faktor risiko cedera muskuloskeletal dikarenakan terjadi gerakan yang berulang-ulang dalam jangka waktu yang lama. Adapun salah satu keluhan muskuloskeletal tersebut adalah Carpal Tunnel Syndrome (CTS).

CTS merupakan salah satu Work-related Musculoskeletal Disorders (WMSDs) atau dapat pula dikatakan Occupational Overuse Syndrome (OOS) dan juga Repetitive Strain Injuries (RSI). Berbagai aktivitas yang menggunakan kekuatan tangan serta gerakan berulang pada jari-jari tangan biasanya dihubungkan dengan keluhan CTS. ${ }^{1}$

CTS membuat saraf medianus menjadi rentan terhadap kompresi atau cedera pada telapak tangan. Jaringan di sekitar saraf menjadi membengkak dan terjadi penebalan pada sendi dan saraf medianus, dimana hal tersebut terjadi karena terdapat peradangan pada bagian dalam terowongan karpal, yang mengakibatkan terhambatnya kecepatan hantar (konduksi) pada serabut saraf yang akan berdampak gejala pada pergelangan tangan dan tangan. ${ }^{2}$

Sindroma ini mempunyai angka kejadian yang cukup tinggi. Pada tahun 1992, De Kom di Belanda melaporkan insidensi CTS sebanyak $0,6 \%$ untuk pria dan $9,2 \%$ untuk wanita pada populasi dewasa. ${ }^{3}$ Di Amerika Serikat, diperkirakan terjadi peningkatan insiden dari 1-3 per 1000 penduduk menjadi 150 per 100 penduduk setiap tahun dengan prevalensi melebihi 500 kasus per 1000 penduduk. ${ }^{4}$ Kasus CTS $(>50 \%)$ bersifat idiopatik tetapi sebagian kondisi lain juga dapat menjadi penyebab terjadinya CTS. Faktor risiko CTS adalah gerakan berulang, gerakan kecepatan tinggi, posisi sendi yang tidak nyaman, tekanan langsung pada pergelangan tangan, vibrasi, dan postur pergelangan tangan yang dipertahankan untuk jangka waktu lama. ${ }^{5}$ 
Pekerja yang bekerja dengan mesin gerinda dimana mesin gerinda merupakan mesin pemotong yang menghasilkan suatu getaran yang digunakan untuk memotong benda, meratakan dan membelah benda, mengasah benda dan membentuk benda sering sekali pekerja mengalami berbagai keluhan seperti nyeri pada bagian tangan khususnya bagian pergelangan tangan. Keluhan yang sering dialami tersebut masih dianggap suatu masalah yang tidak harus diselesaikan dengan sesegera mungkin, bahkan dikatakan menjadi hal yang biasa bagi mereka. ${ }^{6}$

Hal serupa juga terjadi pada pekerja pemahat patung. Pekerja yang mengandalkan kekuatan fisik seperti pemahat patung dalam proses kerjanya yang masih sebagian besar memakai alat bantu kerja tradisional yaitu berupa palu dan alat bantu kerja lainnya. Tekanan dan gerakan secara berulang-ulang juga sering kali membuat pekerja mengalami beberapa keluhan pada tangannya, mulai dari rasa nyeri maupun kesemutan. Namun, hal tersebut tidak menjadi masalah yang terlalu serius bagi pekerja dikarenakan belum adanya efek yang berarti dari permasalahan tersebut. Pekerja masih tetap bisa untuk bekerja seperti biasa. Namun, apabila gejala tersebut tidak sesegera mungkin ditangani maka akan berdampak buruk bagi pekerja dan akan menghambat pekerja dalam melakukan pekerjaannya. ${ }^{5}$ Penelitian ini bertujuan untuk mengetahui gambaran umum tentang hubungan pekerja di kabupaten Gianyar, khususnya tipe pekerjaan pemahat patung dan menggunakan mesin gerinda terhadap Carpal Tunnel Syndrome.

\section{METODE}

Penelitian ini dilakukan di Singapadu, yaitu tepatnya di Banjar Negari Singapadu Tengah, Sukawati, Gianyar, dimana pada desa tersebut terdapat tukang ukir yang juga mengaplikasikaan mesin gerinda. Penelitian ini dilaksanakan pada bulan Februari sampai Maret 2019. Populasi target dalam penelitian ini adalah pekerja yang mempunyai faktor risiko terjadinya CTS. Populasi terjangkau dalam penelitian ini adalah seluruh pekerja dengan mesin gerinda dan pemahat patung serta pekerjaan selain pekerjaan tersebut di Kabupaten Gianyar.

Analisis univariat adalah analisis data yang dilakukan untuk menganalisis setiap variabel yang digunakan dalam penelitian secara deskriptif dengan melakukan perhitungan distribusi frekuensi data demografi dari masing-masing variabel penelitian. Analisis univariat dalam penelitian ini berfungsi untuk mengetahui apakah terdapat faktor risiko terjadinya CTS pada pekerja pemahat patung dan pekerja dengan mesin gerinda pada pekerja yang dapat dibuktikan dengan cara melakukan test spesifik flick sign.

Analisis bivariat adalah analisis data yang dilakukan pada variabel independen dan variabel dependen dalam penelitian. Analisis bivariat dalam penelitian ini menggunakan uji statistic chi square dan uji mantel - haenszel yang berfungsi untuk mengetahui hubungan antara variabel independen yaitu pekerjaan pemahat patung dan pekerja gerinda dengan variabel dependen yaitu CTS.

Penelitian ini telah disetujui oleh Komisi Etik Penelitian Fakultas Kedokteran Universitas Udayana/Rumah Sakit Umum Pusat Sanglah Denpasar. Ethical clearance/keterangan kelaikan etik dengan nomor 595/UN14.2.2.VII.14/LT/2020. Informed consent telah diperoleh dari sampel penelitian sebelum melakukan penelitian.

\section{HASIL \\ Karakteristik Sampel Penelitian}

Penelitian observasional analitik dengan metode pendekatan cross-sectional mengenai faktor risiko pekerjaan menggerinda dan memahat patung dengan kejadian CTS ini melibatkan 104 orang responden di Banjar Negari Singapadu Tengah, Sukawati, Gianyar, Bali. Pengumpulan data dengan metode wawancara kepada responden mengenai nama, umur, masa kerja, lama kerja perhari dari responden yang dilakukan dari periode Februari sampai Maret 2019 memperoleh gambaran karakteristik pekerjaan menggerinda dan memahat patung di Banjar Negari Singapadu Tengah, Sukawati, Gianyar berdasarkan kelompok usia, didapatkan rata-rata usia pekerja yang menjadi responden penelitian ini adalah 41 tahun. Hal ini menunjukkan bahwa pekerja di Banjar Negari Singapadu Tengah, Sukawati, Gianyar berada pada usia produktif.

Tabel 1. Distribusi Pekerjaan Menggerinda dan Memahat patung di Banjar Negari Singapadu Tengah, Sukawati, Gianyar Berdasarkan Karakteristik Sosiodemografi

\begin{tabular}{lccc}
\hline \multicolumn{1}{c}{ Karakteristik } & Mean \pm SD & Frekuensi & Persentase \\
\hline Usia (tahun) & $41,47 \pm 10,139$ & & \\
Lama kerja (tahun) & $6,92 \pm 4,419$ & & \\
\hline Pekerjaan & & & \\
\hline \multicolumn{2}{c}{ Menggerinda } & 52 & $50 \%$ \\
Memahat & 52 & $50 \%$ \\
\hline CTS & & \\
\hline \multicolumn{1}{c}{ Ya } & 71 & $68,3 \%$ \\
$\quad$ Tidak & 33 & $31,7 \%$ \\
\hline
\end{tabular}

Pada data Tabel 1 lama kerja rata-rata responden dalam penelitian ini adalah sekitar 7 tahun. Distribusi responden berdasarkan kategori pekerjaan yakni sebanyak 52 orang $(50 \%)$ pekerjaan menggerinda dan 52 orang $(50 \%)$ pekerjaan memahat patung. Sebagian besar pekerja yakni 71 orang $(68,3 \%)$ dengan keluhan CTS. 
Tabel 2. Distribusi Frekuensi Hasil Pemeriksaan Fisik CTS Pekerjaan Menggerinda dan Memahat patung di Banjar Negari Singapadu Tengah, Sukawati, Gianyar

\begin{tabular}{lcc}
\hline \multicolumn{1}{c}{ Jenis } & Frekuensi & Persentase \\
Pemeriksaan & & \\
\hline Tes Phalen & & \\
Tidak Nyeri & 15 & $14,4 \%$ \\
Sedang & 37 & $35,6 \%$ \\
Berat & 52 & $50 \%$ \\
Tes Tinel & & \\
Tidak Nyeri & 27 & $26 \%$ \\
Sedang & 32 & $30,8 \%$ \\
Berat & 45 & $43,3 \%$ \\
Tes Flick Sign & & \\
Bertambah & 0 & $0 \%$ \\
Berkurang & 104 & $100 \%$ \\
Tes Wrist Extension & \\
Tidak Nyeri & 23 & $22,1 \%$ \\
Sedang & 30 & $28,8 \%$ \\
Berat & 51 & $49,0 \%$ \\
\hline
\end{tabular}

Tabel 2 menunjukkan distribusi frekuensi hasil pemeriksaan fisik CTS pada pekerjaan menggerinda dan memahat patung di Banjar Negari Singapadu Tengah, Sukawati, Gianyar dimana 52 orang (50\%) pekerja menunjukkan nyeri berat saat dilakukan tes phalen. Tes phalen dilakukan dengan cara menekuk kedua tangan pada kedudukan fleksi secara maksimal selama 30 detik sampai 2 menit. Bila terjadi rasa nyeri, tebal atau parestesia di daerah persyarafan saraf medianus tes dinyatakan positif.

Hasil pada Tabel 2 juga menunjukkan 43,3\% responden mengeluh nyeri berat saat dilakukan tes tinnel. Tes tinnel dilakukan dengan cara perkusi ringan pada saraf medianus pergelangan tangan akan terjadi rasa nyeri yang menjalar dari lengan ke jari I sampai setengah jari ke IV. Ketukan dengan perkusi yang mengetuk seluruh 14 fleksor retinakulum. Pemeriksaan lain yang dilakukan untuk mendiagnosis CTS adalah memeriksa Flick's sign di mana responden diminta mengibas-ibaskan tangan. Jika didapatkan keluhan pada responden lebih berkurang atau keluhan menghilang saat mengibas-gibaskan tangan maka akan dapat mengarah pada diagnosa CTS. Hasil Tabel 2 menunjukan 104 responden (100\%) merasa keluhan berkurang saat diperiksa Flick's sign. Pemeriksaan berikutnya adalah wrist extension test di mana responden diminta untuk ekstensi pada tangan secara maksimal dan dilakukan secara bersamaan pada ke dua tangan sehingga nantinya dapat di bandingkan. Test ini dilakukan selama 60 detik sampai 2 menit apabila muncul tanda-tanda seperti gejala CTS, maka tes ini mengarah ke diagnosis CTS. Hasil Tabel 2 menunjukan 51 responden (49\%) merasa nyeri berat saat dilakukan wrist extension test.

Tabel 3. Analisis Faktor Risiko Jenis Pekerjaan dan Kejadian CTS

\begin{tabular}{ccccc}
\hline Jenis Pekerjaan & CTS & Tidak CTS & OR $(95 \%$ Cl) & Nilai p \\
\hline Menggerinda & $38(73,1 \%)$ & $14(26,9 \%)$ & $1,563(0,679-3,595)$ & 0,294 \\
Memahat & $33(63,5 \%)$ & $19(36,5 \%)$ & \\
\hline
\end{tabular}

Tabel 4. Analisis Faktor Risiko Jenis Pekerjaan dan Kejadian CTS

\begin{tabular}{ccccc}
\hline Jenis Pekerjaan & CTS & Tidak CTS & OR $(95 \%$ Cl) & Nilai p \\
\hline Memahat & $33(63,5 \%)$ & $19(36,5 \%)$ & $0,64(0,278-1,472)$ & 0,294 \\
Menggerinda & $38(73,1 \%)$ & $14(26,9 \%)$ & & \\
\hline
\end{tabular}

Analisis bivariat dalam penelitian ini menggunakan uji statistik chi square dan uji mantel-haenszel yang berfungsi untuk mengetahui antara variabel independen yaitu pekerjaan menggerinda dan memahat patung dengan variabel dependen yaitu carpal tunnel syndrome. Sebanyak $73,1 \%$ pekerjaan menggerinda mengalami CTS, sedangkan hanya $26,9 \%$ yang tidak mengalami CTS. Dalam kelompok pekerjaan memahat patung, terdapat sebanyak $63,5 \%$ yang mengalami CTS, sedangakan 36,5\% diantaranya tidak mengalami CTS. Risiko pekerjaan menggerinda mengalami CTS sebesar 1,563 kali pekerjaan memahat $(95 \% \mathrm{Cl}=0,679-3,595)$, sedangkan risiko pekerjaan memahat patung mengalami CTS sebesar 0,64 kali pekerjaan menggerinda $(95 \% \mathrm{Cl}=0,278-1,472)$ namun hasil tersebut tidak bermakna secara statistik $(p=0,294)$.

\section{DISKUSI \\ Distribusi frekuensi hasil pemeriksaan fisik CTS}

Berdasarkan hasil pemeriksaan fisik yang dilakukan pada responden penelitian ini yakni berupa pemeriksaan phalen test, tinel test, flick sign dan wrist extension memperoleh hasil 52 orang $(50 \%)$ pekerja menunjukkan nyeri berat saat dilakukan tes phalen. Hasil serupa juga diperoleh dalam penelitan Sihombing dimana $84 \%$ pekerjaan yang menggunakan mesin gerinda menunjukkan hasil tes phalen positif. ${ }^{7}$ Penelitian oleh Lazuardi juga memperoleh hasil serupa dimana $78,58 \%$ pekerjaan memahat patung yang melakukan gerakan berulang dengan palu merasakan nyeri saat dilakukan tes phalen. Tes phalen dilakukan dengan cara menekuk kedua tangan pada kedudukan fleksi secara maksimal selama 30 detik sampai 2 menit. Bila terjadi rasa nyeri, tebal atau parestesia di daerah persyarafan saraf medianus tes dinyatakan positif. Ketika pergelangan tangan di tekuk atau fleksi akan menimbulkan penekanan pada saraf medianus, pada kondisi CTS dimana terjadi penekanan kronis pada saraf medianus atau terjadi peradangan saraf, akan menimbulkan rasa nyeri pada tes ini. ${ }^{5}$ Patofisiologi manuver Phalen melibatkan dua aspek. Pertama, pasien 
dengan sindrom carpal tunnel mengalami peningkatan tekanan di terowongan karpal saat istirahat, yang diperburuk oleh fleksi pergelangan tangan pada maneuver Phalen sehingga menimbulkan sensasi nyeri. Kedua, serabut saraf di saraf median pada kondisi CTS mengalami proses patologis yang mengakibatkan sensasi paresthesia atau kebas ketika saraf dikompresi di antara ligament karpal transversal dan tendon fleksor pada maneuver Phalen (Urbano, 2000). Tes phalen baik untuk mendiagnosis CTS dengan sensitifitas $75 \%$ dan spesifitas $95 \%{ }^{8}$

Penelitian ini juga mendapatkan hasil 43,3\% responden mengeluh nyeri berat saat dilakukan tes tinnel. Pada penelitian Juniari didapatkan hasil serupa dimana 78,8\% rekatzsponden menunjukkan hasil tes tinne/ positif. Tes tinnel dilakukan dengan cara perkusi ringan pada saraf medianus pergelangan tangan akan terjadi rasa nyeri yang menjalar dari lengan ke jari I sampai setengah jari ke IV. ketukan dengan perkusi yang mengetuk seluruh 14 fleksor retinaculum. ${ }^{9}$ Patofisiologi tanda Tinel diduga melibatkan mekanosensitivitas abnormal yang melibatkan saraf medianus, menghasilkan pelepasan aferen pada tingkat saraf yang menghasilkan sensasi nyeri dan kesemutan yang menunjukkan gejala khas CTS, di tingkat seluler, tanda Tinel muncul mungkin disebabkan oleh eksitasi membrane yang tidak normal. Tes tinnel baik untuk mendiagnosa CTS dengan sensitifitas 64\% dan spesifisitas mencapai $99 \%{ }^{7}$

Pemeriksaan Flick's sign pada responden menunjukkan 104 responden (100\%) merasa keluhan berkurang saat diperiksa. Tes Flick's sign dilakukan dimana pasien diminta mengibas-ibaskan tangan. Jika didapatkan keluhan pada pasien lebih berkurang atau keluhan pasien menghilang saat mengibas-gibaskan tangan maka akan dapat mengarah pada diagnosa CTS. Gerakan mengibaskan tangan pada pemeriksaan flick dapat meningkatkan tekanan arteriolar, aliran darah, dan aliran balik vena, yang dapat mengurangi edema dan menormalkan stabilitas listrik serat otonom, sehingga meringankan gejala CTS. ${ }^{7}$

Pemeriksaan berikutnya adalah wrist extension test dimana pasien diminta untuk ekstensi pada tangan secara maksimal dan dilakukan secara bersamaan pada kedua tangan sehingga nantinya dapat di bandingkan. Test ini dilakukan selama 60 detik sampai 2 menit apabila muncul tanda-tanda seperti gejala CTS, maka tes ini menyongkong diagnose CTS. Gerakan ekstensi pada pergelangan tangan juga disebut dengan reverse phalen test, dimana maneuver ini memberikan tekanan pada saraf medianus yang menimbulkan rasa nyeri akibat penekanan pada saraf medianus pada kondisi CTS. ${ }^{10}$ Penelitian ini menunjukan 51 responden (49\%) merasa nyeri berat saat dilakukan wrist extension test.

\section{Analisis Faktor Risiko Jenis pekerjaan dan Kejadian CTS}

Analisis bivariat penelitian ini memperoleh hasil sebanyak 73,1\% pekerjaan menggerinda mengalami CTS, sedangkan hanya $26,9 \%$ yang tidak mengalami CTS. Dalam kelompok pekerjaan memahat patung, terdapat sebanyak $63,5 \%$ yang mengalami CTS, sedangakan $36,5 \%$ diantaranya tidak mengalami CTS.

Hasil penelitian ini juga sejalan dengan penelitian Pangestuti dan Widajati dimana 87,2\% pekerja gerinda di PT DPS memiliki keluhan CTS. Keluhan CTS tersebut sebagian besar dirasakan responden setelah beberapa menit menggunakan mesin gerinda. ${ }^{11}$ Keluhan CTS yang paling banyak dirasakan oleh responden adalah nyeri sebesar $64,1 \%$. Berdasarkan hasil analisis uji chisquare penelitian Pangestuti dan Widajati terdapat hubungan yang sedang antara penggunaan Alat Perlindungan Diri (APD) dengan keluhan CTS dan terdapat hubungan yang kuat antara intensitas getaran mesin gerinda dengan keluhan CTS. ${ }^{11}$ Penelitian yang dilakukan oleh Budiono juga menyatakan bahwa terdapat hubungan yang signifikan antara getaran mesin gerinda dengan CTS. ${ }^{12}$

Hasil dari penelitian Sihombing juga menunujukkan bahwa 84\% pekerja gerinda positif dengan gejala CTS. Berdasarkan analisis bivariat penelitian oleh Sihombing juga diperoleh nilai $p=0,020$ dimana $p<=0,05$ yang menunjukkan ada hubungan yang signifikan antara intensitas getaran dengan gejala CTS. Tanda korelasi positif memiliki makna bahwa ke dua variabel memiliki arah hubungan yang berpola searah. Hal ini dapat diartikan bahwa semakin tinggi intensitas getaran maka semakin tinggi juga gejala CTS, namun sebaliknya semakin rendah tingkat intensitas getaran maka semakin rendah juga gejala CTS. Menurut teori getaran, gejala CTS bisa disebabkan oleh efek dari penggunaan jangka panjang alat yang bergetar pada saraf median di carpal tunnel. ${ }^{6}$

Getaran setempat pada pergelangan tangan oleh karena alat perkakas seperti mesin gerinda akan merangsang kontraksi tendon, mencederai saraf perifer, mengurangi sensasi tangan akibat konstriksi vaskuler atau vasospasme mikrosirkulasi ke saraf perifer. Cedera mikroskopik, mikrosirkulasi arteriosklerosis lokal menyebabkan peningkatan volume pada terowongan karpal yang menekan nervus medianus, sehingga menimbulkan rasa nyeri, terdapat kelemahan dan gangguan fisik yang dikenal dengan CTS. Gejala CTS bisa disebabkan oleh efek dari penggunaan jangka panjang alat yang bergetar pada saraf median di karpal tunnel. Paparan alat getar yang di genggam selama beberapa hari dapat menimbulkan edema epineural pada saraf median. ${ }^{6}$

Penelitian Cindyastira menunjukkan 65\% pekerja mengalami keluhan musculoskeletal disorders (MSDs) karena getaran alat yang digunakan. Analisis data penelitian Cindyastira menunjukkan bahwa variabel yang berhubungan dengan keluhan MSDs adalah umur $(p=0,002)$, masa kerja $(p=0,007)$, kebiasaan olahraga $(p=0,030)$ dan sikap kerja $(p=0,015)$ sedangkan, variabel yang tidak berhubungan dengan keluhan MSDs adalah intensitas getaran $(p=0,864)$ dan lama kerja $(p=0,079) \cdot{ }^{13}$

Pekerjaan memahat patung dalam pekerjaanya melakukan gerakan berulang-ulang dengan menggunakan alatalat seperti palu kayu, pahat ukir dan peralatan yang lainnya. Apabila dalam melakukan pekerjaan tersebut tidak memperhatikan posisi tangan yang ergonomis maka hal tersebut dapat membahayakan pekerja, yang dimana dapat menimbulkan rasa nyeri, kebas, kesemutan, dan apabila hal tersebut tidak diperhatikan maka dapat memperparah kondisi pekerja. Salah satu penyakit yang dapat di timbulkan pada pekerjaan ini adalah CTS. Pekerjaan dengan gerakan menggenggam berulang-ulang dan memberikan tekanan langsung pada pergelangan tangan akibat menggunakan palu dan alat pahat ukir seperti yang dilakukan pemahat patung dan pengrajin tatakan batu berisiko menimbulkan CTS. Penelitian Mallapiang menunjukkan 37,2\% pekerja pengrajin tatakan batu mengalami CTS. Pekerja pemecah batu yang 
menggunakan alat seperti palu juga berisiko mengalami kejadian CTS dimana 78,6\% pekerja pemecah batu postif mengalami CTS. ${ }^{14}$

Saat ini, masih banyak terdapat pekerja pemahat patung dan pekerjaan dengan mesin gerinda yang tidak mengetahui risiko pekerjaan tersebut, sehingga penelitian ini dapat menjadi upaya preventif bagi pekerja dan menambah pengetahuan pembaca mengenai hubungan pekerjaan menggerinda dan pemahat patung terhadap CTS. Kelemahan dari penelitian ini adalah keterbatasan dalam mengedukasi pekerja berisiko karena banyaknya tenaga kerja yang mengakibatkan upaya preventif tidak maksimal, sehingga hal tersebut berdampak pada angka kejadian CTS. Perbedaan penelitian ini dengan penelitian terdahulu adalah penelitian ini menggunakan sampel pekerja berisiko pemahat patung dan pekerjaan menggerinda di kabupaten Gianyar. Kesamaan antara penelitian ini dan penelitian terdahulu yaitu menggunakan pendekatan cross sectional sehingga masih cukup terbatas dalam mengamati hubungan kedua faktor dengan baik.

\section{SIMPULAN}

Berdasarkan penelitian yang telah dilakukan terdapat faktor risiko antara pekerjaan menggerinda dan memahat patung terhadap CTS, yaitu pekerjaan menggerinda sebagai faktor risiko CTS yaitu sebanyak $73,1 \%$ yang mengalami CTS, sedangkan hanya $26,9 \%$ yang tidak mengalami CTS. Pekerjaan memahat patung sebagai faktor risiko CTS yaitu sebanyak 63,5\% yang mengalami CTS, sedangakan 36,5\% di antaranya tidak mengalami CTS. Pekerjaan menggerinda memiliki faktor risiko CTS sebesar 1,563 kali pekerja pemahat $(95 \% \mathrm{Cl}=0,679-3,595)$. Hal tersebut diakibatkan karena getaran dalam durasi waktu yang lama dan juga masa kerja yang tinggi dengan postur kerja yang tidak ergonomis.

\section{DAFTAR PUSTAKA}

1. Suherman B. Beberapa Faktor Kerja yang Berhubungan dengan Kejadian CTS pada Petugas Rental Komputer di Kelurahan Kahuripan Kota Tasikmalaya. Tasikmalaya: Universitas Siliwangi; 2012.

2. Aizid R. Babat ragam penyakit paling sering menyerang orang kantoran. Jakarta: Universitas Negeri Yogyakarta; 2011.

3. Lazuardi Al. Determinan Gejala Carpal Tunnel Syndrome (CTS) pada pekerja pemecah batu (Studi pada Pekerja Pemecah Batu di kecamatan Sumbersari dan Sukowono Kabupaten Jember). Artikel IImiah Hasil Penelitian Mahasiswa. 2016.

4. Budiono A. Hubungan Antara Getaran Mekanis Alat Kerja dengan Carpal Tunnel Syndrome terhadap Getaran Lengan Tangan pada Operator Mesin di Bagian Moulding Perum Perhutani Unit 1 Jawa Tengah. Skripsi. Universitas Negeri Semarang. 2005.

5. Enda N. Hubungan Repetitive Motion Terhadap Keluhan Carpal Tunnel Syndrome Pada Pekerja Pembuat Pempek Di Kota Palembang. 2017.

6. Sihombing AP. Hubungan Sikap Kerja Dengan Musculoskeletal Disorders Pada Penjahit Di Pusat Industri Kecil Menteng Medan 2015.

7. Urbano FL. Tinel's Sign and Phalen's Maneuver: Physical Signs of Carpal Tunnel Syndrome. Hospital Physician. 2000:39-44.

8. Katz JN, Simmons BP. Carpal tunnel syndrome. New England Journal of Medicine. 2002;346(23):1807-12.

9. Juniari GA, Triwahyudi A. Hubungan Antara Masa Kerja Terhadap Keluhan Carpal Tunnel Syndrome (CTS) pada Pegawai Perempuan di Kampus Universitas Dhyana Pura yang Bekerja Menggunakan Komputer. VIRGIN: Jurnal Ilmiah Kesehatan Dan Sains. 2015;1(2):162-9.

10. Physiopedia contributors. Phalen's Test [Internet]. Physiopedia; 2020. Available from: https://www.physiopedia.com/index.php?title=Phalen\%E2\%80\%99s Test\&oldid=245119.

11. Widajati N, Pangestuti AA. Faktor yang Berhubungan dengan Keluhan Carpal Tunnel Syndrome pada Pekerja Gerinda di PT Dok dan Perkapalan Surabaya. Indonesian Journal of Occupational Safety and Health. 2014;3(1):3807.

12. Cindyastira D, Russeng SS, Wahyuni A. Hubungan Intensitas Getaran Dengan Keluhan Muskuloskeletal Disorders (MSDs) Pada Tenaga Kerja Unit Produksi Paving Block CV. Sumber Galian Makassar Univ Hasanuddin. 2014;113.

13. Tana L. Sindrom terowongan karpal pada pekerja: pencegahan dan pengobatannya. Jurnal Kedokteran Trisakti. 2003;22(3):99-104.

14. Mallapiang F, Wahyudi AA. Gambaran faktor pekerjaan dengan kejadian carpal tunnel syndrome (CTS) pada pengrajin batu tatakan di Desa Lempang Kec. Tanete Riaja Kabupaten Barru Tahun 2015. Al-sihah: The Public Health Science Journal. 2014;7(1). 